\title{
LONG-DISTANCE CONNECTIONS OF THE SOUTH-EASTERN PERIPHERIES OF THE LUBLIN REGION AT THE TIME OF THE LUSATIAN CULTURE IN THE LIGHT OF ARCHIVAL AND NEWLY DISCOVERED MATERIALS
}

\begin{abstract}
Kłosińska E. M. and Sadowski S. 2017. Long-distance connections of the south-eastern peripheries of the Lublin region at the time of the Lusatian culture in the light of archival and newly discovered materials. Sprawozdania Archeologiczne 69, 391-408.

Considering the background of the Lublin Region (Poland), the valley of the Sieniocha river can be described as an area replete with bronze objects dated to the period of the Lusatian culture. Most of them are imports, as their manufacturing was usually beyond the local metallurgists' skills, chiefly due to the lack of raw materials. The finds originate from distant territories and represent various influences (Thraco-Cimmerian, Scythian, of the Hallstatt culture, Scandinavian or from the area of the Volga-Kama rivers). Their presence indicates that the valley used to be a territory, where different cultural connections functioned. The location of the land was conducive to movement of people and cultural interactions.
\end{abstract}

Keywords: Sieniocha river, Lusatian Culture, Bronze Age, Early Iron Age, bronze artefacts.

Received: 18.05.2016; Revised: 26.05.2017; Accepted: 10.06.2017

\footnotetext{
* Institute of Archaeology at Maria Curie-Skłodowska University; M. Curie-Skłodowska Sq. 4, 20-031 Lublin, Poland; e-klosinska@o2.pl

** Institute of Archaeology at Maria Curie-Skłodowska University; M. Curie-Skłodowska Sq. 4, 20-031 Lublin, Poland; sylwestersadowski@o2.pl
} 


\section{INTRODUCTION}

At the present time, the south-east fringes of the Lublin region can be considered areas of the Central and Eastern Poland relatively well researched in terms of archaeology. Within the drainage basin of the Huczwa river and of other tributaries of the upper Bug river (especially Sołokija) undoubtedly there were favourable conditions for settlement, and an investigation of the map of Lusatian culture sites leads to the conclusion that in the Bronze Age and Early Iron Age the settlement pattern there was particularly compacted (Kłosińska 2005a, 161-162, fig. 1, 16). These areas are attractive not only for the local Lusatian community, but also for newcomers coming from the outside, sometimes from very distant territories. In recent years this phenomenon garnered a lot of attention, and new finds of foreign provenance have gradually entered scientific circulation. The nature of this subject has been studied, emphasising the possibility of the movement of people together with their items and the idea of their use and production (c.f. Kłosińska 2005a; Sadowski 2012). Obviously, within the collection of the archaeological sources from the area in question the greatest attention was focused on metals (bronze, and recently increasingly more frequent products made of iron). These are the most spectacular finds, and their origin, cultural attribution and the feasibility of dating usually did not cause much difficulty. It is estimated that today the number of such artefacts within the south-eastern peripheries of the Lublin region reaches around 150 pieces. It is worth noting that the long-distance connections of this area are reflected also by the pottery vessels formed under the impact of foreign influences; there are even imported items! Additionally, clear changes took place in the funerary rite as exemplified by the inhumation practices. In varying intensities, these phenomena were recorded within all physical-geographical regions of the south-eastern part of the Lublin region. The following can be mentioned as an example: in the area of Roztocze there are two iron shaft-hole axes of Scythian or Thraco-Scythian origin (Roztocze Sadowski 2012; Werchrata, Lubaczów district - Kłosińska 2003), in the Bug river basin area (Polish: Pobuże) - pins, arrowheads, and nail-shaped earrings of analogous origin, as well as a unique Nordic projectile point of the Borbjerg type from IV period of the Bronze Age (Stary Machnów, Tomaszów district - Kłosińska 2007a; 2009, 247-252, figs. 1, 2; 2010, 242-243, 244-245, figs. 1: 3; 2: 2, 4; 3: 2, 3; 4: 3a), and within the Sokal Ridge items coming from the Early Iron Age metallurgical workshops of Kuyavia and Lesser Poland (the hoard from Wożuczyn, Tomaszów Lubelski district - Żurowski 1927, footnote 117; Kłosińska 2007b, 123, photo 9), and of Thraco-Cimmerian origin - strap distributor from Podhajce, Tomaszów Lubelski district and a fragment of cheek-piece from Honiatyń, Hrubieszów district (Kłosińska 2007 c, 276, fig. 2: 10, 15), as well as of Thraco-Scythian origin - a set of arrowheads from Żulice, Tomaszów Lubelski district (Kłosińska 2013a), etc. We do not mention here numerous earlier imports from the Dniester river basin and from the outside of the arc of the Carpathian Mountains, which include the forms developed in the metallurgical production of the Gáva culture or Gáva-Holihrady culture (some 
axes, etc. - cf. Kłosińska 2006a, 307-308, 314; 2007d, 232-233). In this study we intend to focus on the finds from the area of the Hrubieszów Basin, and in particular on a small part thereof - the Sieniocha river basin.

\section{THE HRUBIESZÓW BASIN}

When it comes to the landscape of the Lublin region, in many ways the Hrubieszów Basin is a distinctive physical-geographical unit. Gently rolling terrain covered with diverse - mostly very fertile - soil, well developed river network in the broad valleys (of the Huczwa and Bug rivers and their tributaries), diversified flora and fauna, and a lack of clear communication obstacles (Nogaj-Chachaj 1991; 2001) - for centuries all this attracted people of different cultures and promoted settlement. The area of the basin became the scene of flourishing not only of cultural entities of the Neolithic and Early Bronze Age, but also of migration and settlement of the Goths during the Roman period, as well as lush and full of political tensions development of stronghold settlement in the Early Middle Ages. A voluminous bibliography has been devoted to these issues (cf. Gumiński 1989; Głosik 1968; Kokowski 1995; Stańczyk 1996). Certainly, the topic of the cultural relations and settlement patterns in the younger stages of the Bronze Age and Early Iron Age in the area has been less popularized, although excavations had been carried out on sites dated to the aforementioned stretch of the prehistory. A review of the results of the mentioned works, as well as of the recent discoveries demonstrate that the period of Lusatian culture settlement in the Hrubieszów Basin cannot be regarded as an insignificant episode. There was a dense settlement network here, the main axis of which was the Huczwa river together with its tributaries (Fig. 1). This network consisted of numerous microregions, each of which was composed of a cemetery (or cemeteries), a settlement (or settlements) and sites of undetermined nature accompanying them (identified on the basis of incidental and surface discoveries of pottery, flint, as well as bronze and iron finds), which roughly determined the range of the economic exploitation done by the inhabitants (Kłosińska 2005a; 2007b).

The inflow of imported items within the extent of this physical-geographical unit was not uniform. Their clear concentration is noted by the lower course of the Huczwa river. For example, one should mention sleeved axes from beyond the arc of the Carpathian Mountains (the hoard from the Hrubieszów area, Hrubieszów district - Cichoszewska 1922-1924, 132), vessels mimicking Gáva culture designs (cemetery in Gródek, Hrubieszów district - Niedźwiedź 1999, 107), and, finally, weapons and ornaments that can be associated with the Scythian milieu (arrowheads and earring from Gródek, Hrubieszów district - Niedźwiedź 1998, 149-152, fig. 1: 1-4; the iron blade of acinaces from Ślipcza, Hrubieszów district - Kłosińska 2009, 253-255, fig. 3). There are also discoveries within the cultural blending zone of the Lusatian and Vysotsko cultures that is distinguished in the area in question. Among them there are a few inhumation graves, which have been analysed 
in detail elsewhere (Kłosińska 2005a, 171-178, fig. 6-11). However, pottery imports, such as the mug with a high handle from Gródek (a stray find from the settlement area), and a bowl fragment with imprints made with a bronze stamp in the shape of the letter "S" and filled with white paste from Świerszczów, Hrubieszów district, site 3 (from a settlement feature), are the novelties in the lower reaches of the Huczwa river that has not been previously published. These unique finds probably origin from the realm of the Chernoles culture and should be dated to the Late Bronze Age and Early Iron Age.

Within the Hrubieszów Basin the valley of the Sieniocha river is the area of another aggregation of imported items. At the present stage, one might even venture to say that considering the Lublin region this area is particularly (probably to highest level) replete with the items of this type.

\section{THE DRAINAGE BASIN OF THE SIENIOCHA RIVER}

Micro-regional level analysis usually provides good results for the reconstruction of the history and culture of prehistoric communities. The fortunes of such prehistoric "little homeland" usually reflect the fortunes of slightly larger territories. Therefore, it can be assumed that with the selected small area, just as in a lens, the fate not only of the entire Hrubieszów Basin, but also of the Lublin region was focused. The drainage basin of the Sieniocha river, together with its confluence with the Huczwa river, is indeed such an area (Fig. 1; 2). From the archaeological point of view the area in question should be considered as very well investigated - in the course of various research works and discoveries ample information has been obtained about more than 100 archaeological sites dated to the younger stages of the Bronze Age and the Early Iron Age (Fig. 2). This knowledge was gathered during professional surface surveys and excavations. Unfortunately, a lot of the data come also from illegal surveys with metal detectors done by so-called explorers, for whom the Sieniocha river basin is an extremely attractive place to explore, especially in the vicinity of the village of Komarów-Osada, Zamość district, where in 1920 the renowned Polish-Soviet battle took place, as well as near the Early Middle Ages stronghold in Czermno, Tomaszów district - the alleged capital of Czerwień Towns.

Until recently, the issues related to settlements and economy have not had sufficient grounds. However, a few sites were researched here, at which specialized studies were carried out. This allowed the distinguishing of species of animals and plants that could have been used by the residents of those settlements during the Bronze Age and Early Iron Age. Among the bred animals there is certified presence of the following: bovine animals, swine, goats/sheep, horse, and fowl; among the wild animals distinctive are such species as: deer, roe deer, fox, fish, birds (cf. Woźniak 2009; Kłosińska 2012a, 149). When it comes to crops, only the presence of barley is certified. Most likely the diet was supplemented by gathering and, moreover, at the sites located within the discussed region accessories related to agriculture survived - such as querns, grinding stones and sickles (Kłosińska 2007b, 116). 


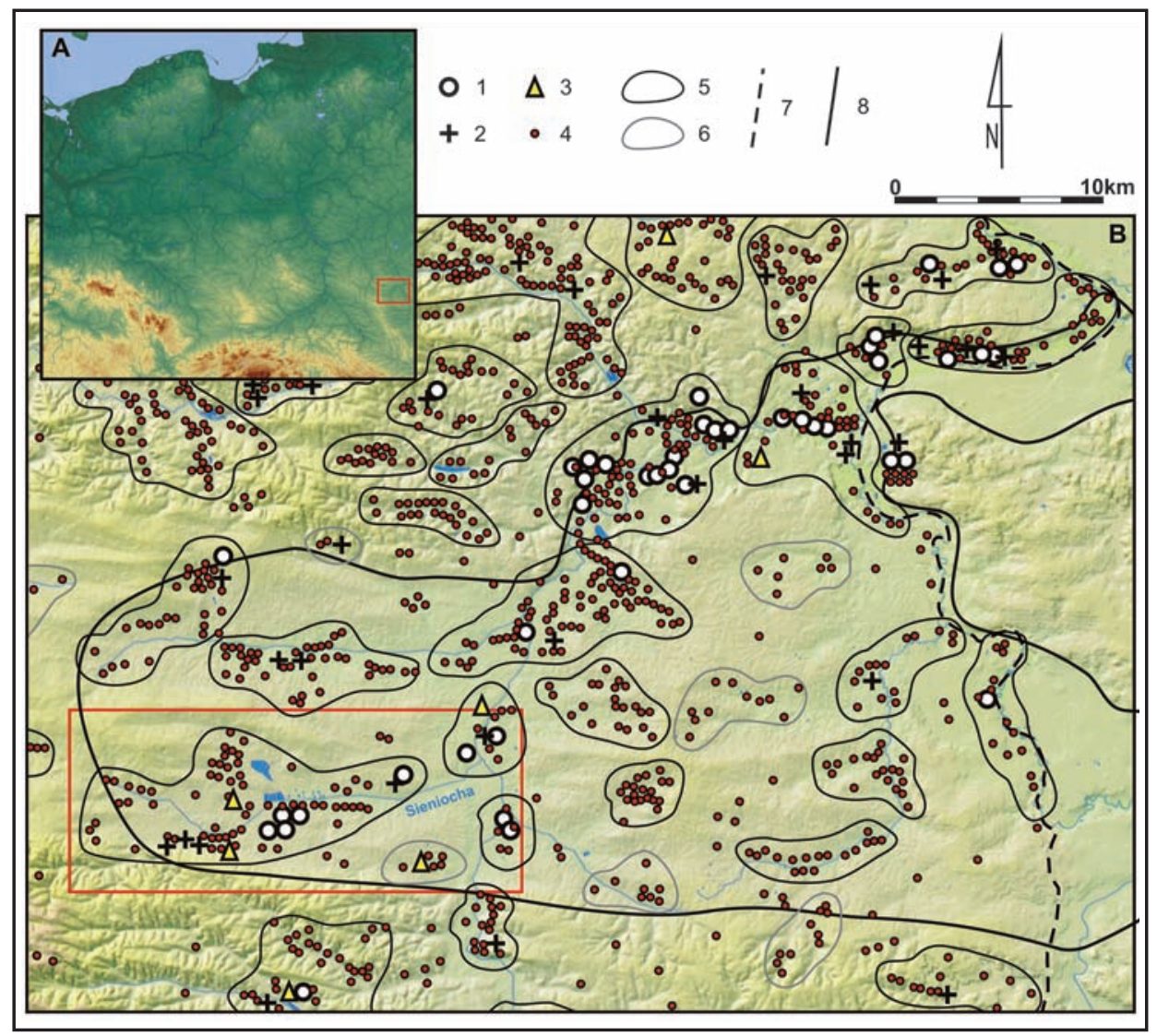

Fig. 1. Settlement of the Lusatian culture population in the Hrubieszów Basin (the Sieniocha river basin is marked on red). 1 - settlement; 2 - cemetery; 3 - hoard; 4 - find of unidentified nature; 5 - areas with compact settlement; 6 - areas with dispersed settlement; 7 - east border of the examined area; 8 - extent of the Hrubieszów Basin; A - location of the Hrubieszów Basin - base map after www.maps-for-free.com; B - the Hrubieszów Basin - base map according to L. Gawrysiak 2004 


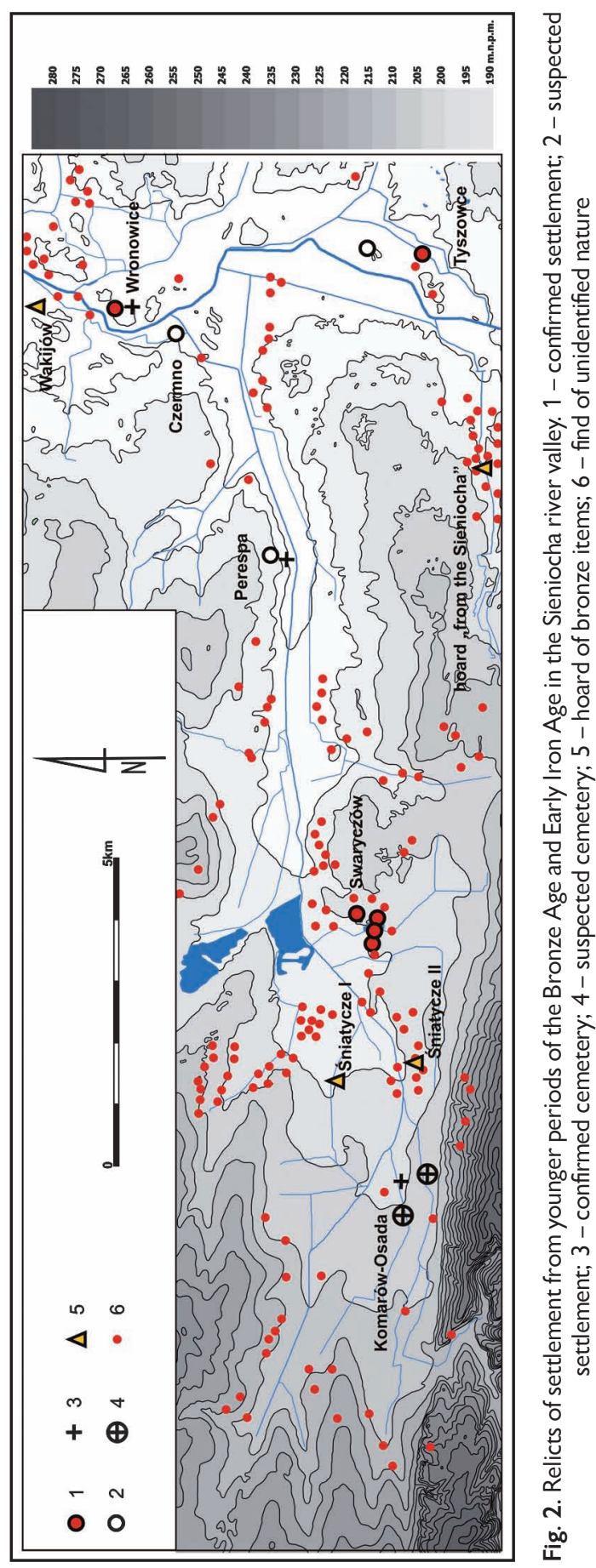




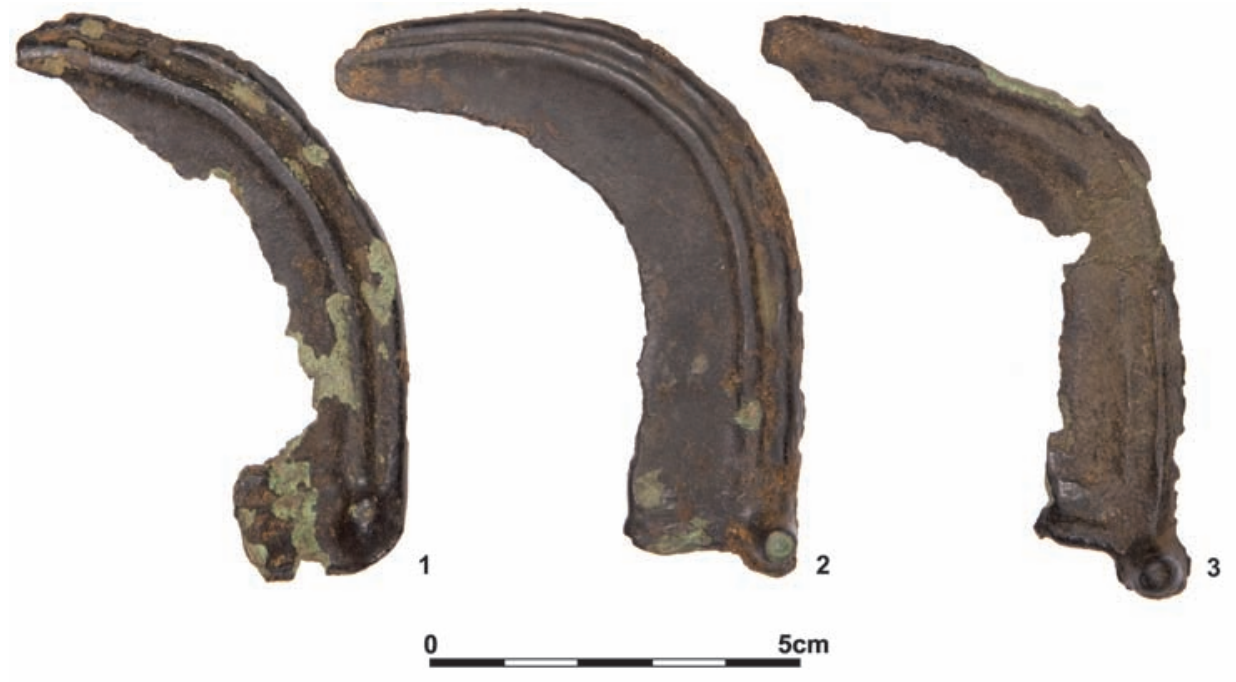

Fig. 3. Śniatycze II. Hoard of bronze sickles (photo by S. Sadowski)

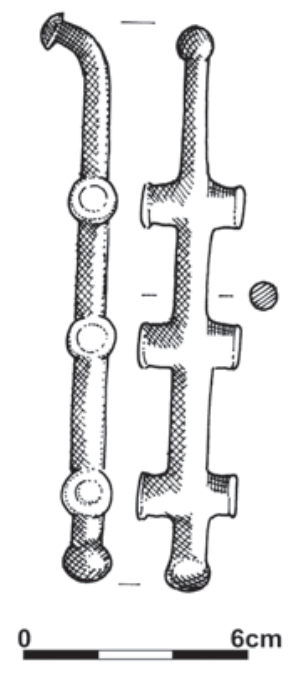

Fig. 4. Komarów-Osada. Bronze cheek-piece (drawing by E. M. Kłosińska; redrawn by T. Demidziuk) 

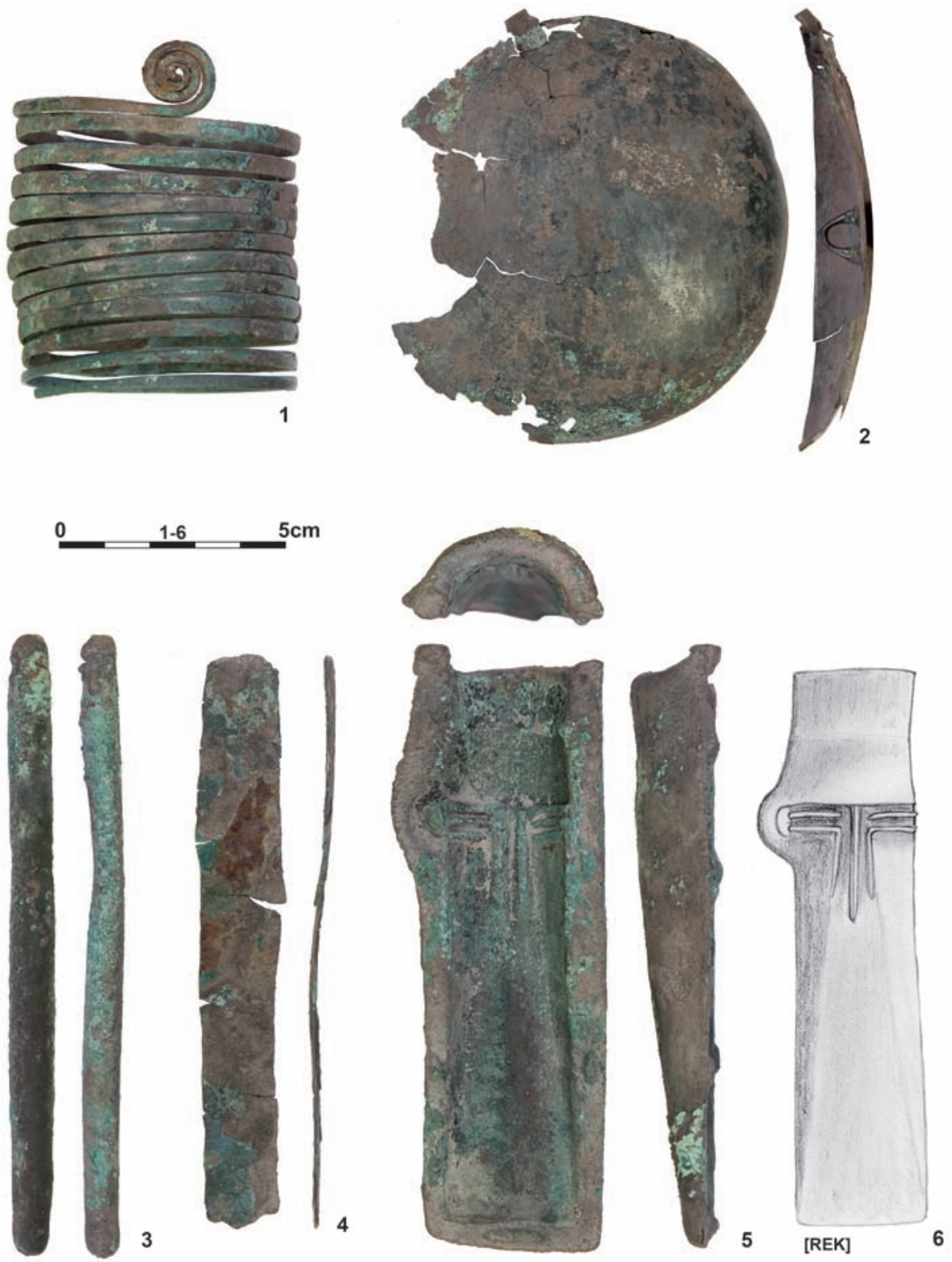

Fig. 5. Hoard of bronze items "from the Sieniocha river area"

(1-5 - photo by S. Sadowski; 6 - reconstruction of the axe cast - drawing by E. M. Kłosińska) 
The wide valley of the Sieniocha river with extensive floodplain was the factor particularly conducive to settlement. In the vicinity of Komarów-Osada the valley is nearly $2.5 \mathrm{~km}$ wide, at Swaryczów, Zamość district, and Perespa, Tomaszów Lubelski district, it varies between 1 and $0.5 \mathrm{~km}$ and, finally, near Czermno it connects with an extensive, over $3-\mathrm{km}$ wide valley of the Huczwa river. In the historical times these were wetlands subject to frequent floods, and the memory of these local disasters has been kept until modern times in the local names - "Błota" (Eng. "Muds") and "Żuławy" (Eng. "Alluvial deposits"). On the other hand, in prehistoric times, there were extensive water bodies here which were subject to peat accumulation. During the times of the Lusatian culture these reservoirs were already covered with rushes, which is reflected by a significant percentage of reed and bulrush in the composition of botanical remains. Pools of floodwaters were the habitat for fish and shellfish, as well as birds refuge. Palynological profiles clearly show the increasing importance of grass formations, and the analysis of the macro-remains confirms the presence of flood meadows on the edge of floodwater pools with sedges and wetland varieties of horsetails and ferns. Also, relics of vegetation accompanying humans next to dwellings and in cultivated fields - plantains, goosefoot family, sorrel and tarragon were identified (Urban 2004, passim). It is not unlikely that these weeds had an important role to play in supplementing the diet of the local population, as well as in the medicine of the time (cf. Lityńska-Zając 2005, 273-277). During the time of the development of the Lusatian culture in the Sieniocha river valley heather family formations and hazel spread, while some deciduous trees (elm) gradually declined (cf. Urban 2004). This certifies a significant human impact on the environment and destruction of expanses of forest through a slashand-burn economy (Ralska-Jasiewiczowa 1999, 123). An interesting curiosity of the natural environment in the area are enclaves of steppe vegetation still existing today.

Until recently, Wronowice, Hrubieszów district, site 5a was the best identified settlement developed with rectangular buildings. It is located near the confluence of the Sieniocha river with the Huczwa river (Wichrowski 1989). Not only agriculture and husbandry were the foundation of the existence of the residents of the aforesaid settlement, but also food processing, pottery production, and metalworking. The last mentioned activity is certified by metallurgical waste moulds extracted from a metallurgist's firepit. On the other hand, the issue of local salt production, which is allegedly evidenced by finds of salt-production vessels (called briquetage) remains open. The settlement in Swaryczów, site 1, where archaeological excavations have been conducted (led by S. Sadowski since 2005), is another Lusatian culture settlement from the Sieniocha river area that is animating expectations of the researchers.

The matters of the funeral rite and spiritual culture of the inhabitants of the micro-region can be satisfactorily reconstructed based on the cemeteries in: Komarów-Osada, site 9, and Perespa, site 54, which were studied to various extents. These were cremation row necropolises, mostly with cinerary urns. In the course of the research a specific relationship between the burials and the parts of the carcasses deposited in them has been demonstrated 
(Kłosińska 2006b, 65; Woźniak 2009). Furthermore, the use of flint and fossils in the funerary treatments has also been pointed out (Kłosińska 2012a). What is more, the anatomical order of the human remains in urns has been attested, as well as the adaptation of the size of the cinerary urns to the age of the deceased (Kłosińska 2006b, 65; Kłosińska and Piotrowski 2005, 392). Both burial grounds were used primarily in the Younger and Late Bronze Age (Niedźwiedź 1990, 33) and probably still at the beginning of the Early Iron Age (Kłosińska and Piotrowski 2005, 392; Kłosińska 2006b, 68).

Most likely the location of the majority of the sites reflects the course of the then shoreline of the wetlands and the extent of meadows and peats in the valley of the Sieniocha river. It seems that the people of the Lusatian culture especially preferred areas located between isolines marking 190 and $200 \mathrm{~m}$ above sea level that were clearly tending to the river valley. Studies have shown that the people of this cultural entity inhabited the discussed area primarily in the Bronze Age. At the end of this epoch, and during the onset of the Early Iron Age due to distinct climatic changes (c.f. Dzięgielewski 2012, fig. 1) certain habitats (settlements together with cemeteries) probably began to disappear. Apart from the settlements in Wronowice, site 5, and Swaryczów there are no signs of further development of the Lusatian culture settlements from the Sieniocha river (or from the Huczwa river either) whereabouts into the Early Iron Age. It can be assumed that at that time the methods of inhabitation of the analysed area changed significantly. There is an ongoing research focused on the location of settlements and their building development (Swaryczów); so far, cemeteries dated to this time span of prehistory have not been found, and the only vessel from the Early Iron Age containing burned human bones and two beads of black glass (probably urn?), discovered in the space of the Roman Period cemetery in Swaryczów, has no exact primal location because it is interpreted as a supposed ancient "exhumation".

Bronze finds usually of distant origins from the Sieniocha river area are the subject of our particular attention. Their presence forces us to recognize the valley of this river as an arena within which variety of cultural connections was implemented. The area of the valley, thanks to its shape, favoured movement of people and establishing contacts. In the light of today's advancement of the research, this small part of the Lublin region can be seen as an area particularly heavily saturated with bronze items (as many as four hoards were found here) that are very diverse when it comes to the form, and originating from very distant territories. The fact that imports dominated among these items cannot be doubted as their production was rather beyond the capabilities of local metallurgists, mainly due to the shortages of raw materials. In the area by the Sieniocha river and near its mouth to the Huczwa river the most spectacular discoveries of bronze items were made in the vicinity of Komarów-Osada, Śniatycze, Swaryczów (all in Zamośc district) and Wakijów, Tomaszów Lubelski district (Fig. 2). As mentioned above, the finds are characterized by varied and sometimes very distant provenance; they are also very diverse in terms of chronology. 
One of the earliest finds in the local Lusatian culture environment is the first of the hoards deposited in the grounds of the village of Śniatycze, site 89. The set consisted of bronze ornaments of a horse bridle (Kłosińska 2008, 266-273, fig. 1-6). The find was located on a small elevation near a river and it should not be ruled out that this place originally was adjacent to a body of water of some sort, or was surrounded by wetlands. As the individual elements were tightly bundled together it suggests that some kind of packaging was used. The deposit consisted of three discs and nine thong fittings in various stages of preservation. The items were made with extreme precision of thin sheet ornamented from underside. For the execution of the ornament a compass and a thin punch were used.

Although the set from Śniatycze has already entered scientific circulation, it seems that it was prematurely associated with the Late Bronze Age (c.f. Kłosińska 2008, 292) during which in Eastern and Central Europe Cimmerian expansion took place. The hoard is probably older and comes from as early as the end of the Middle and the beginnings of the Younger Bronze Age (HaA). Even though when considering the discs one can indicate counterparts from the Carpathian Basin appearing there in the phases of HaA1 (the Kurd horizon in Hungary - Mozsolics 1985, pl. 137: 2; 150: 1), as well as HaB1 and HaB3 (the Křenůvki and Černotín horizons in northern Moravia - Salaš 2005, pl. 339A: 31, and others), the thong fittings are recorded within a narrower time frame generally limited to the Middle Bronze Age. Particularly numerous counterparts of these items are present in Slovakia, in assemblages characteristic of the Drslavice-Ořechov horizon - BrD, the Martinček-Bodrog horizon - HaA1, and the Mušov 2-Přestavlky horizon - HaA1 (the beginnings of HaA2) (c.f. Novotná 1980, pl. 69: 60; Salaš 2005, 146-147, pl. 220: 307-309 and others). An analogous fitting is also known from a grave of the early Tarnobrzeg phase of the Lusatian culture (HaA1) in Grodzisk Dolny (Leżajsk district, Subcarpathian province) (Czopek 1996, 26, 137, Pl. 33:13). To the south from the arc of the Carpathian Mountains the aforementioned horizons of metal items were identified in the case of assemblages attributed to the Lusatian culture or the Middle-Danube Urnfield culture (Salaš 2005, 138, fig. 24). Probably the thong fittings discovered in Śniatycze originated from the areas inhabited by these cultural entities.

The deposit of the three sickles that was recently discovered in Śniatycze, site 94 (Fig. 3), should be counted among similarly early finds in the Lusatian culture environment by the Sieniocha river. They were stacked closely, one on top of the other, and undoubtedly constituted a set hidden in some kind of organic packaging in the river or in its vicinity. The aquatic environment of the deposition is suggested by a thick layer of brownish-black wetland patina present on the surface of each of the items. These finds represent the knobbed sickle form with a straight base and high arched back. Although they are very damaged, it can be assumed that originally they were similar to one another in terms of size and weight. The differences are only perceptible in the case of short, horizontal ribs that are located above the base. There are respectively one (Fig. 3: 1), two (Fig. 3: 2) and three base ribs present (Fig. 3: 3). 
Knobbed sickles constitute a group of items with a similar appearance that were common in the Urnfield milieu of Central Europe. The design of the tool developed in the Middle Bronze Age turned out to be so useful that it was repeatedly produced in barely altered versions also in the Younger Bronze Age. Knobbed specimens are relatively numerous in the Lusatian culture within the Polish lands (Gedl 1995). Many of these items were made on the spot, perhaps also in the Lublin region. Due to the slight formal differentiation, these items are difficult to classify and to locate in time. Hence, the sickles from Śniatycze can be broadly dated to the Middle and Younger Bronze Age. Very clear wear traces around the cutting edge allow accepting that at that time these tools were used according to their intended purpose - to cut cereals, grasses and other plants. However, another very interesting "aspect" of these artefacts might also be examined. It is thought that they were a kind of money from the pre-monetary times (cf. Sommerfeld 1994), or a part of a "metric and weighting" system of the time. Being easy to carry around, they also could have been a source of "measured" and "weighed" raw material (Kłosińska 2005b, 217). We do not know whether the short ribs (their number) at the base of the sickles were of any importance when it comes to these issues (e.g. they meant the size, weight, etc.). Furthermore, we can risk a claim that the sickles were objects with certain symbolic meaning. They could have been associated with vegetative magic, rebirth of nature, and at cemeteries with disjunction of the deceased from the world of the living (Frazer 1971, 109), but also with the rebirth of the dead in the world of ancestors. It is quite likely that this was the role of a single slightly differently shaped bronze knobbed sickle that was driven into the ground between urn graves at a nearby cemetery in Komarów-Osada (Kłosińska and Klisz 2003, 62).

The discoveries recently made in the Lublin region (including the ones by the Sieniocha river) provide the basis for assumption that a wave of pre-Scythian influences occurred here, which is reflected by the bronze items of Thraco-Cimmerian origin. This phenomenon took place already at the end of the Bronze Age. In extensive meadows and peatbogs in the upper reaches of the Sieniocha river near Komarów-Osada a unique find was discovered - a bronze cheek-piece (Fig. 4). Relatively deep underground position (in a wall of a deepened ditch of a land development system, about 1.5 metres from the modern land surface) as well as the nature of the patina suggest a humid environment of the deposition of the item. The exquisitely well preserved item covered with brown swamp patina represents a fairly popular in the Thraco-Cimmerian environment cheek-piece of the Dunakömlöd type, the Fügöd variant (cf. Chochorowski 1993, 62, 70, 186, fig. 3, map 3). The cheekpieces of the Dunakömlöd-Fügöd type undoubtedly referred to earlier specimens with similar function (Malaya Tsymbalka, Dunakömlöd-Füzesabony) that have tubular inlets for thongs in their body and terminals fitted with tiny plates or knobs. Items belonging to the listed types are characterized by significant similarities and by some researchers they are considered to be the same "Malaya Tsymbalka" (Terenožkin 1976, 151, fig. 88). However, in the latest classification of cheek-pieces from Central Europe they are listed as type I (Metzner-Nebelsick 2002, 214-215, fig. 97). In that area the discussed elements of horse 
tack were frequent constituents of assemblages and stray finds (Metzner-Nedbelsick 2002, fig. 98; 99; 104:1; 127: 6; 8: 25; 19: 7; 36: 1-4 and others). Cheek-pieces of the Dunakömlöd-Fügöd type were in use mainly at the end of the Bronze Age $\left(2^{\text {nd }}\right.$ half of the HaB3 subperiod). Their findings spread beyond the Carpathian Basin (where their design had been developed) and they were also noted by the upper Elbe river, by the upper Dniester river, and in northern Italy (Chochorowski 1993, 186, 191, 193, 200, 206, fig. 3). Geographically the nearest equivalents to the item from Komarów-Osada were found among the hoards from the Dniester river area like in the alleged deposit from Pidsadky (Pustomyty district, Lviv province, in the set from Medynia (Halych district, Ivano-Frankivsk province), or in the well known hoard from Holihrady (Zalishchyki district, Ternopil province) (Żurowski 1948-1949, 163, 167, 170, 203-204, pl. 37:1, 2, 3, 3a, 4, 5; Chochorowski 1993, fig. 42:1-3). The cheek-piece from Komarów-Osada has the closest analogies, not only in terms of the morphology, but also the size, in the two specimens of the last mentioned deposit, which contained also other elements of a bridle, such as cross-shaped thong distributors, phalerae and figure-8-shaped knobs (Chochorowski 1993, fig. 42:4-52). The hoards from the Dniester river region consisting of the elements of a horse bridle, once considered to be Thracian assemblages from the Early Iron Age (Żurowski 1948-1949, 208-210), in the light of the new research should be associated with Central European Cimmerian horizon, or, in fact, with the "Thraco-Cimmerian" cultural milieu of the Carpathian-Danubian area (Chochorowski 1993, 186, 270, 273-274; 1999, 370; Metzner-Nebelsick 2002, 74, 212). The hoard from Holihrady, in which there were cheek-pieces very similar to the specimen from Komarów-Osada, belongs to the younger series of deposits (dated to the final stages of the $\mathrm{HaB} 3$ ) of the classic materials from the Cimmerian horizon (Chochorowski 1993, 191-193). This assemblage is also placed within the entire $8^{\text {th }}$ century BC (Metzner-Nebelsick 2002, 74-75). The hoards from the Dniester river area, containing the cheek-pieces of the Dunakömlöd-Fügöd type, reflect the phenomenon of Thraco-Cimmerian influence in the areas inhabited by the population of the Vysotsko culture (Pidsadky) (Bandrivskiy, Krushelnitska 1998, 235, fig. 20:11) and the Holihrady culture (Medynia, Holihrady) where - as it is believed - horse tack of the Thraco-Cimmerian type appeared only at the end of the existence of the later culture (Krushelnitska 1985, 99). It cannot be ruled out that the escalation of depositing bronze hoards coincided with the Cimmerian pressure on the areas by the Dniester river and in the western Podolia. This phenomenon took place around the mid- $7^{\text {th }}$ century BC and led to serious cultural changes (Chochorowski 1999, 384). Both the cheek-piece from Komarów-Osada and a fragment of a possibly similar item from Honiatyn (unearthed by a left tributary of the Bug river - Warężanka, just $40 \mathrm{~km}$ from Komarów-Osada - Kłosińska 2007d, 231, fig. 9: f), as well as other finds of eastern origin, for example, a damaged cheek-piece of the Chernogorovka type (?) from Gródek (Rogatko, 1990, 190-192, fig. 10, 11), the above mentioned damaged knob-distributor of the Dunakömlöd type (?) from Podhajce (Kłosińska 2007c, 276), as well as a few bronze discs (unpublished materials) reflect the existence of the Cimmerian horizon or Thraco-Cimmerian 
horizon in the south-eastern peripheries of the Lublin region. These finds contradict the once expressed opinion that in the eastern part of the Lusatian culture this phenomenon did not occur (Bukowski 1976, 140-141). The existence of similar materials was also confirmed in the Tarnobrzeg group dated to the $\mathrm{HaB}_{3}$ (Gedl 1999, 72; Czopek 2004, 74, 106, 108). Given the location of these finds mentioned here one might assume that the territories of the Subcarpathia and Western Volhynian Upland, and especially those localities that were subject to a particularly intensive settlement of the population of the Lusatian culture, were within the range of the Thraco-Cimmerian horizon. The cheek-piece of the Dunakömlöd-Fügöd type could have been lost while forcing the way through extremely vast wet meadows in the vicinity of Komarów-Osada, probably at the time when the nearby cemetery of the population of the Lusatian culture was used, i.e. during the Late Bronze Age (cf. Niedźwiedź 1991, 19).

A find of a few bronze items discovered last year, to which we refer - due to the lack of precise location - as "from the Sieniocha river area" (Fig. 5A) reflects the completely different directions of affiliation of the territory discussed here. The place of the discovery is not precisely identified, but with a high degree of probability, even close to certainty, one can locate it between the village of Przewale and Zamlynie in Tomaszów Lubelski district (perhaps on the land belonging to the village of Wojciechówka), near a small cluster of the Lusatian culture sites registered during the Archaeological Survey of Poland (Polish: Archeologiczne Zdjęcie Polski) (Fig. 2). Undoubtedly, this is a set and there is this very peculiar proof to it: its elements were originally wrapped in a hide with fur, and numerous traces of animal hairs have been preserved in the patina covering on each of them. This package was additionally wrapped with a string, the relic of which is also preserved in the patina. Each item from this hoard is extremely interesting on its own and - besides a bar of raw material - finds no equivalent in the Lublin region. Two damaged ornaments were discovered here: a spiral bracelet (Fig. 5:1) and a large disc (Fig. 5:2), the bar of raw material (Fig. 5:3), a rectangular sheet cut from a larger piece (Fig. 5:4), and a half of a bronze casting mould (Fig. 5:5). This set of finds seems to indicate that raw material and scrap was accumulated here, therefore everything that could have been intended for remelting.

These items are currently being analysed (e.g. determination of the alloy composition, the function of the casting mould, identification of the species of the animal whose fur was used to wrap these bronze items) and for this reason they will not be a subject of a detailed presentation at this point. Among them the bronze casting mould attracts particular attention (Fig. 5:5). It probably was used in the production of wax or bronze casts of axes of the Mälar-Akozino type. Bronze casting moulds belong to extremely rare metallurgical accessories. In the Polish lands only a few specimens come from the western zone covered by the Lusatian culture inhabitation (Baron et al. 2014). The item from the Sieniocha river whereabouts might be an import from a very distant territory, i.e. the Volga-Kama zone or central Sweden. Both these areas for a few centuries were connected by a communication route called the north-eastern copper track or the trapper track (Okulicz 1976, 88). 
The researchers studying the axes of the Mälar-Akozino type do not agree on their provenance, assuming that the prototype of these tools could have been developed in the west (central Sweden - Okulicz 1976, 99) or in the east of Europe (Volga-Kama - Kuzminykh 1996). Until today, the controversy in this matter has not reached a definite and satisfactory solution. However, it should be taken for granted that in Central Europe these were rare products; they are associated with late phases of the development of the Lusatian culture (Okulicz 1976, 99). In the Polish lands they were made in clay waste casting moulds at the settlement of the West Baltic Barrow culture dated to the Hallstatt D period in Tarławki, Węgorzewo district, Warmian-Masurian province (Waluś 1982, 245).

According to the current state of knowledge, the axes of the Mälar-Akozino type were produced in the clay forms (cf. Kuzminykh 1996; Čivilytė 2008, 155). Until now, the bronze form from the Sieniocha river area has no known counterpart. What is more, neither among the northern materials (Sweden) nor north-eastern (Russia) there are axes, which would correspond exactly to this form (Fig. 5: 6 - reconstruction of the cast axe). Therefore, this item remains a mystery for now, though the observation of certain elements of the set this item is a part of, seems to indicate a "northern trace". Cylindrical, 12-coil bracelet/ armlet, made from a fairly wide massive rod with tapered ends, terminated with small, 3-coil discs (Fig. 5: 1) is a product made probably in the Nordic zone. Such artefacts appeared in north-western Poland (Pomerania, Lubusz Land) and in the adjacent areas of northern Germany (Mecklenburg, Schleswig-Holstein) in sets dated to the Late Bronze Age (Sprockhoff 1956, 174, pl. 35; 36; von Brunn 1981, 107, pl. 34; 39; 41; 55: 218; 59). Ornaments of similar appearance were used also in Scandinavia, for example, in the Danish Islands during the $5^{\text {th }}$ period of the Bronze Age (Baudou 1960, 60). In the context of the northern finds there emerges yet another puzzling issue of the Lusatian culture associations with the zone of central Sweden (areas of Stockholm and Lake Mälar). It is supposed that in the younger periods of the Bronze Age small groups of the Lusatian culture population reached these areas, among them also women involved in pottery production (Bukowski 1998, 349-353; further literature there). The presence of characteristic pottery was recorded at the Hillunda estate (today a borough of Stockholm) and the cultural characteristics of almost the entire assemblage are consistent with the models developed in the Polish lands in the Lusatian culture milieu, not only when it comes to the morphology, but also from technological point of view (Dąbrowski 1984). In the Late Bronze Age the northern direction of long-distance connections had to be strong and, therefore, it cannot be ruled out that at that particular time the set of bronze items discussed here with the distinctive bracelet and the mould for the production of axes of the Mälar type reached the Sieniocha river area from the north. This phenomenon seems to confirm the tendency already observed by researchers of movement over long distances of products and manufacturers thereof; this intensified especially during the younger periods of the Bronze Age and in the Early Iron Age (Bukowski 1998, 353, further literature there). 
Another spectacular find comes from the village of Wakijów, Tomaszów Lubelski district, which is located in the valley of the Huczwa river, slightly up the stream from the mouth of the Sieniocha river. It is a set of massive ornaments deposited in a humid environment. The hoard is dated to the HaD period (Blajer 2001, 368). Two big items from the hoard attract one's attention: a fibula and a necklace. An openwork lense-shaped fibula together with triangular hanger, also openwork, and sound-making pendants constituted probably one entity (Poklewski 1954, 271). Motifs of triangles and circles repeated here indicate the stylistic uniformity of both items. It seems that the best counterparts to this impressive ornament are to be found in broadly understood Hallstatt culture world, where there was fashion for similar jewellery, sometimes of monstrous size. The hanger and sound-making pendants refer to the finds from the territory of Hungary, Slovakia (Poklewski 1954, 271-272) and Switzerland (Schmid-Sikimić 1996, 177-178, pl. 63: A101), and in the Polish territory one may compare it to the damaged pendant from the hoard in Świdnik by the Dunajec river, Nowy Sącz district, Lesser Poland (Żurowski 1927, 65, 71).

The massive necklace from the hoard from Wakijów was probably made in Kuyavia during the younger times of the Early Iron Age (Poklewski 1954, 268). At that time, a few peculiar types of ornaments were developed in Kuyavian (Stanomin) metallurgical centre, for instance, single-direction twisted necklaces with long flatenned arms and loop terminals (Durczewski 1961, 96; Kostrzewski 1964, 20-21). Such items were often present in local multi-element finds of metal items (Cofta-Broniewska 1996, 61). The necklaces spread widely outside Kuyavia and this is confirmed not only by the discovery from Wakijów, but also by specimens from western Ukraine (Sulimirski 1931, 135-136, pl. XXVI: 1) and Slovakia (Novotná 1984, 52-56, pl. 53).

The next phase of long-distance connections of the Sieniocha river valley in the days of the Lusatian culture occurred during the Early Iron Age and is marked by finds of Scythian provenance. They consist primarily of two bronze thong distributors in the shape of a bird of pray discovered in the neighbourhood of Swaryczów (Kłosińska 2008, 273-280, fig. 8: 1, 2). Both were elements of a horse bridle, stabilizing intersection of thongs on the sides of a horse's snout, additionally improving the aesthetics of a horse tack. The distributors were adapted to thin, round (?) thongs or twine.

These items clearly refer to elements of horse bridle made of bone or metal that were frequently present in Scythian culture. In the south-eastern fringes of the Lublin region (outside the valley of the Sieniocha river) another such item was discovered in Przewodów, Hrubieszów district (Antoniewicz 1928, 134). Most likely they came from the territory of the West Podolian group of the forest-steppe Scythian culture (Kłosińska 2008, 293; 2012b). Analogous bronze specimens were included in the grave goods of burials interred underneath burial mounds in Ukraine, by the middle reaches of the Dniester river - in localities within the Ivano-Frankivsk province: Horodnitsa (Horodenka district) and Bratishiv (Tlumach district) (Sulimirski 1936, 23, 48, 100, pl. 8: 5d; Bandrivskiy 1998, fig. 1: 2, 3). The topic of the West Podolian group influences in the area of the Lublin region is a very 
extensive one and it requires separate studies elsewhere. It should be mentioned here that in the Early Iron Age these impacts may have contributed to major changes within the eastern zone of the Lusatian culture. Also, the possibility of migration from the east, especially from the forest-steppe zone, is considered (cf. Kłosińska 2008, 293, further literature there).

Additionally, bronze arrowheads from Wolica Brzozowa, Zamość district, and Swaryczów also testify to the presence of eastern interactions by the Sieniocha river in the Early Iron Age. They represent various forms and their relationship with Scythian weaponry is obvious. The arrowheads as well as a fragment of a projectile point from Swaryczów bear clear traces of use - they have bent or broken barbs. It is worth mentioning that most of the metal items of eastern provenance concentrate in the south-eastern part of the Lublin region (the middle and lower reaches of the Huczwa river) (cf. Kłosińska 2007d; 2013), in the areas where there are remains of steppe vegetation preserved to this day (Nogaj-Chachaj 2001, 8-9). This phenomenon might possibly be related to exploration done by the people from the east in the search for good places to implement pastoral economy (cf. Kłosińska 2008, 292, further literature there).

Last, but not least, it is worth mentioning that the archaeological sources of metal items of foreign provenance from the Sieniocha river are constantly on the increase. In 2015 further seven arrowheads, two nail-shaped earrings, and other interesting bronze artefacts were obtained from the analysed area. In the near future these finds will be subject to a thorough analysis but at this stage of the assessment it can be said that within this latest collection there are products of Thraco-Scythian provenance (Vekerzug culture) and also ones imported from the zone of the Hallstatt culture.

\section{CONCLUSION}

In conclusion, it should be stated that during the period of the development of the Lusatian culture in the valley of the Sieniocha river there functioned a settlement complex of major importance. It was characterised by long-distance and multi-directional connections with the cultural centres of the time in Central, Eastern and Northern Europe. During the Bronze Age relations with the Urnfield culture entities of the Carpathian Basin should be noted as well as the onset of the Thraco-Cimmerian influences coming probably from the Dniester river basin. The Early Iron Age was a time of connections not only with the Hallstatt civilization and the Scythian world, but also with distant metallurgical centres by the Volga and Kama rivers or in the Scandinavian Peninsula. The population from the Sieniocha river also used metal designs developed in the Kuyavian metallurgical centre.

The valley of the Sieniocha river maintained its role of an important transport route that at times connected even very distant territories, the situation continuing during the Roman Period and in the Early Middle Ages. As a side note it might be added that during 
the Early Middle Ages there was a route here connecting Kievan Rus' with the west of Europe. At present, this area is definitely off the beaten track of the most frequented traffic channels.

\section{References}

Antoniewicz W. 1928. Archeologia Polski. Zarys czasów przedhistorycznych i wczesnodziejowych na ziem Polski. Warszawa: Wydawnictwo Trzaska, Evert i Michalski.

Badou E. 1960. Die regionale und chronologische Einleitung der jüngeren Bronzezeit im Nordischen Kreis (= Acta Universitatis Stockholmiensis, Studies in North-European Archaeology 1). Stockholm-Göteborg-Uppsala: Almqvist \& Wiksell.

Bandrivs'kyj M. 1998. Zum frühesten Muster des skythischen Tierstils in der Westukraine. In B. Hänsel and J. Machnik (eds.), Karpatenbecken und osteuropäische Steppe. Nomadenbewegungen und Kulturaustausch in der vorchristlichen Metallzeit (40oo-5oo v. Ch.) (= SüdosteuropaSchriften 20, Prähistorische Archäologie in Südosteuropa 12). München-Rahden: Verlag Marie Leidorf GmbH, 467-471.

Bandrivskiy M. and Krushelnitska L. 1998. Osnovni periodi rozvitku Visotskoy kultury (za materialami pokhovalnikh pamiatok). Zapiski Naukovogo Tovaristva imeni T. G. Shewchenka 235 (= Pratsi Arkheologichnoy Komisyi). 193-247.

Baron J., Miazga B. and Nowak K. 2014. Functions and contexts of Bronze age metal casting moulds from Poland. Bulletin de la Société Préhistorique de Françe 111(2), 325-338.

Blajer W. 2001. Skarby przedmiotów metalowych z epoki brąu i wczesnej epoki żelaza na ziemiach polskich. Kraków: Księgarnia Akademicka w Krakowie.

von Brunn W. A. 1981. Eine Deutung spätbronzezeitlicher Hortfunde zwischen Elbe und Weichsel (=Bericht der Römisch-Germanischen Kommision 61). Mainz am Rhein: Philipp von Zabern.

Bukowski Z. 1976. Elementy wschodnie w kulturze tużyckiej u schytku epoki brązu. Wrocław-Warszawa-Kraków-Gdańsk: Ossolineum.

Bukowski Z. 1998. Pomorze $w$ epoce brązu $w$ świetle dalekosiężnych kontaktów wymiennych. Gdańsk: Gdańskie Towarzystwo Naukowe w Gdańsku.

Chochorowski J. 1993. Ekspansja kimmeryjska na tereny Europy środkowej. Kraków: Wydawnictwo UJ w Krakowie.

Chochorowski J. 1999. Żelazny oręż barbarzyńców - wczesna epoka żelaza poza zasięgiem cywilizacji klasycznych. In J. K. Kozłowski (ed.), Encyklopedia Historyczna Świata 1. Kraków: Agencja Publicystyczno-Wydawnicza Opres w Krakowie, 304-395.

Cichoszewska H. 1922-1924. Nowe nabytki Muzeum Wielkopolskiego w latach 1911-1921. Przegląd Archeologiczny 2, 125-134.

Čivilyte A. 2008. Einige Aspekte der bronzezeitlichen Metallurgie in den Baltischen Ländern. In M. Mogielnicka-Urban (ed.), Opera ex aere. Studia z epoki brazu i wczesnej epoki żelaza dedykowane profesorowi Janowi Dąbrowskiemu przez przyjaciót, uczniów i kolegów z okazji siedemdziesięciolecia urodzin. Warszawa: Instytut Archeologii i Etnologii Polskiej Akademii Nauk, 151-158. 
Cofta-Broniewska A. 1996. Metalurgia brązu w świetle źródeł archeologicznych. In A. Cofta-Broniewska and Z. Hensel (eds.), Metalurgia brazu pradziejowych społeczeństw Kujaw (= Studia i Materiały do Dziejów Kujaw 7). Poznań: Wydawnictwo UAM w Poznaniu, 1-127.

Czopek S. 1996. Grupa tarnobrzeska nad środkowym Sanem i dolnym Wistokiem. Rzeszów: Wydawnictwo Poligrafia Mitel w Rzeszowie.

Czopek S. 2004. Cmentarzysko cialopalne z wczesnej epoki żelaza w Knapach. Rzeszów: Wydawnictwo Poligrafia Mitel w Rzeszowie.

Dąbrowski J. 1984. Zur Frage der nordwestlichen Auswirkungen der Lausitzer Keramik. Bemerkungen zur Bearbeitung des Fundmaterials aus Hallunda. Przegląd Archeologiczny 31(1983), 145-158.

Durczewski D. 1961. Skarby halsztackie z Wielkopolski. Przeglad Archeologiczny 35, 7-108.

Dzięgielewski K. 2012. Problemy synchronizacji danych paleoklimatycznych i archeologicznych na przykładzie tzw. wahnięcia subatlantyckiego. In W. Blajer (ed.), Peregrinationes archaeologicae in Asia et Europa Joanni Chochorowski dedicatae. Kraków: Wydawnictwo ProfilArcheo w Pękowicach k/Krakowa, 109-119.

Frazer J. G. 1971. Złota gałąź. Warszawa: Państwowy Instytut Wydawniczy w Warszawie.

Gawrysiak L. 2004. Mapa rzeźby województwa lubelskiego. Lublin: Zakład Geomorfologii UMCS w Lublinie.

Gedl M. 1995. Die Sicheln in Polen. Prähistorische Bronzefunde XVIII/4. Stuttgart: Franz Steiner Verlag.

Gedl M. 1999. Skarb wyrobów brązowych z Przemyśla. Rocznik Przemyski 35(2), 67-74.

Głosik J. 1968. Kultura strzyżowska. Materiały Starożytne 11, 7-114.

Gumiński W. 1989. Gródek Nadbużny. Osada kultury pucharów lejkowatych. Wrocław - Warszawa Kraków - Gdańsk - Łódź: Ossolineum.

Kłosińska E. 2003. Czekan żelazny z miejscowości Werchrata, pow. Lubaczów. Archeologia Polski Środkowowschodniej 6, 219-221.

Kłosińska E. 2005a. Na południowo-wschodnich peryferiach popielnicowego świata - sytuacja kulturowa i osadnicza w młodszej epoce brązu i we wczesnej epoce żelaza w dorzeczu Huczwy i górnego Bugu. In S. Czopek (ed.), Problemy kultury wysockiej. Rzeszów: Wydawnictwo Poligrafia Mitel w Rzeszowie, 161-192.

Kłosińska E. 2005b. Znalezisko brązowego sierpa z okolic Biłgoraja. Archeologia Polski Środkowowschodniej 7, 216-218.

Kłosińska E. M. 2006a. Nowe znaleziska brązowych siekier z tuleją z Lubelszczyzny. Archeologia Polski Środkowowschodniej 8, 307-316.

Kłosińska E. M. 2006b. Sprawozdanie z badań na cmentarzysku ludności kultury łużyckiej w Perespie, pow. tomaszowski w sezonach 2003-2004. Archeologia Polski Środkowowschodniej 8, 63-69.

Kłosińska E. M. 2007a. Nowe zabytki brązowe wschodniej proweniencji z Lubelszczyzny. Archeologia Polski Środkowowschodniej 9, 273-278.

Kłosińska E. M. 2007b. Południowo-wschodnie rubieże Lubelszczyzny w czasach kultury łużyckiej i pomorskiej. In E. Banasiewicz-Szykuła (ed.), Archeologia południowo-wschodniej Lubelszczyzny (= Skarby z Przeszłości 9). Lublin: Wydawnictwo GAUDIUM w Lublinie, 107-131. 
Kłosińska E. M. 2007c. Issues of the East- and Central-European contacts of the Lublin Region in the younger Bronze Age and the early Iron Age in the light of existing research and sources. In J. Baron and I. Lasak (eds.), Long Distance Trade in the Bronze Age and Early Iron Age. Materiały z Konferencji we Wroctawiu 19-20 kwietnia 2005 (= Studia Archeologiczne 40). Wrocław: Wydawnictwo Uniwersytetu Wrocławskiego we Wrocławiu, 269-290.

Kłosińska E. M. 2007d. Lubelszczyzna i Ukraina w młodszych odcinkach epoki brązu i we wczesnej epoce żelaza - pytania o losy wspólne i niewspólne. In L. Bakalarska (ed.), Wspólnota dziedzictwa archeologicznego ziem Ukrainy i Polski. Materialy z Konferencji zorganizowanej przez Ośrodek Ochrony Dziedzictwa Archeologicznego, Lańcut 26-28 X 2005. Warszawa: Krajowy Ośrodek Badań i Dokumentacji Zabytków w Warszawie, 226-249.

Kłosińska E. M. 2008. Einmalige Funde der Kopfgestellverzierung aus dem südöstlichen LublinLand. Sprawozdania Archeologiczne 60, 265-294.

Kłosińska E. M. 2009. Kilka uwag na temat militariów ludności kultury łużyckiej na Lubelszczyźnie. In H. Taras, A. Zakościelna (eds.), Hereditas praeteriti. Additamenta archaeologica et historica dedicata Ioanni Gurba Octogesimo Anno Nascendi. Lublin: Wydawnictwo UMCS w Lublinie, 245-258.

Kłosińska E. M. 2010. Nowe znaleziska brązowe ze Starego Machnowa, pow. Tomaszów Lubelski. Archeologia Polski Środkowowschodniej 10 (2008), 237-248.

Kłosińska E. M. 2012a. Przyczynek do badań nad występowaniem przedmiotów krzemiennych, kamieni i skamielin w grobach ludności kultury łużyckiej na Lubelszczyźnie. Materiały i Sprawozdania Rzeszowskiego Ośrodka Archeologicznego 33, 135-154.

Kłosińska E. M. 2012b. A unique find of Scythian provenance from the Lublin Region. In W. Blajer (ed.), Peregrinationes archaeologicae in Asia et Europa Joanni Chochorowski dedicatae. Kraków: Wydawnictwo Profil-Archeo w Pękowicach k/Krakowa, 335-339.

Kłosińska E. M. 2013a. Żulice, pow. Tomaszów Lubelski - domniemany zespół zabytków z wczesnej epoki żelaza. Materiały i Sprawozdania Rzeszowskiego Ośrodka Archeologicznego 34, 133-137.

Kłosińska E. M. 2013. Research problems of the Lusatian culture in the early Iron age in the LublinRegion in the light of new archaeological findings. In J. Kolenda, A. Mierzwiński, S. Moździoch and L. Żygadło (eds.), Z badań nad kulturq społeczeństw pradziejowych i wczesnośredniowiecznych. Księga jubileuszowa dedykowana Profesorowi Bogusławowi Gedidze w osiemdziesiątą rocznicę urodzin przez przyjaciól, kolegów i uczniów. Wrocław: Wydawnictwo IAiE PAN we Wrocławiu, 424-449.

Kłosińska E. and Klisz T. 2003. Po śmierci ku Słońcu. Z Otchłani Wieków 58, 59-67.

Kłosińska E. and Piotrowski M. 2005. Wstępne wyniki badań wykopaliskowych na wielokulturowym stanowisku 54 w Perespie, gm. Tyszowce, w sezonach 2003-2004. Materiaty i Sprawozdania Rzeszowskiego Ośrodka Archeologicznego 26, 385-408.

Kokowski A. 1995. Grupa mastomęcka. Z badań nad przemianami kultury Gotów w mlodszym okresie rzymskim. Lublin: Wydawnictwo UMCS w Lublinie.

Kostrzewski J. 1964. Skarby i luźne znaleziska metalowe od eneolitu do wczesnego okresu żelaza z górnego i środkowego dorzecza Wisły i górnego dorzecza Warty. Przegląd Archeologiczny 15 (1962), 5-133. 
Krushelnitska L. I. 1985. Vzayemozviazki naselennia Prikarpattia i Volini z plemenami Skhidnoy i Tsentralnoy Evropy (rubizh epoh bronzi i zaliza). Kiiv: Izdatelstvo „Naukova Dumka”.

Kuz'minych S. V. 1995. Osteuropäische und fennoskandische Tüllenbeile des MälarTyps: ein Rätsel der Archäeologie. Fennoscandia Archaeologica 13, 3-27.

Lityńska-Zając M. 2005. Chwasty $w$ uprawach roślinnych $w$ pradziejach i wczesnym średniowieczu. Kraków: Wydawnictwo Instytutu Archeologii i Etnologii PAN w Krakowie.

Metzner-Nebelsick C. 2002. Der „Thrako-Kimmerische” Formenkreis aus der Sicht der Urnenfelderund Hallstattzeit im südöstlichen Pannonien, Teil 1 - Text, Teil 2 - Katalog und Tafeln (= Vorgeschichtliche Forschungen 23). Rahden-Leidorf: Verlag Marie Leidorf GmbH.

Mozsolics A.1985. Bronzefunde aus Ungarn. Depodfundhorizonte von Aranyos, Kurd und Gyermely. Budapest: Akadémiai Kiadò.

Niedźwiedź J. 1990. Badania archeologiczne na stan. 9 w Komarowie. Sprawozdania z badań terenowych $w$ województwie zamojskim $w 1990$ roku. Zamość, 30-33.

Niedźwiedź J. 1991. Czwarty sezon badań na cmentarzysku kultury łużyckiej w Komarowie stan. 9. Sprawozdania z badań terenowych $w$ województwie zamojskim $w 1991$ roku. Zamość, 19-20.

Niedźwiedź J. 1998 Zabytki brązowe z Gródka nad Bugiem stan. 6, gm. Hrubieszów. In J. Ilkjær and A. Kokowski (eds.), 20 lat archeologii $w$ Mastomęczu 1: Weterani. Lublin: Wydawnictwo UMCS w Lublinie, 149-152.

Niedźwiedź J. 1999. Badania ratownicze na cmentarzysku kultury łużyckiej w Gródku nad Bugiem, stan. 1B, pow. Hrubieszów, w 1998 roku. Archeologia Polski Środkowowschodniej 4, 107-112.

Nogaj-Chachaj J.1991. Środowisko geograficzne Wyżyn Lubelsko-Wołyńskich w okresie atlantyckim i subborealnym. In. J. Gurba (ed.), Schylek neolitu i wczesna epoka brazu w Polsce środkowowschodniej (materiały z konferencji) (= Lubelskie Materiaty Archeologiczne 6), 39-46.

Nogaj-Chachaj J. 2001. Człowiek i środowisko przyrodnicze Kotliny Hrubieszowskiej u schyłku plejstocenu i w holocenie. In. A. Kokowski, H. Landecka, and D. Kopciowski (eds.), Rzymskie dzieje Kotliny Hrubieszowskiej (= Skarby z Przeszłości 3). Lublin: Oficyna Wydawnicza ”ELPress" w Lublinie, 7-19.

Novotná M. 1980. Die Nadeln in der Slowakei. Prähistorische Bronzefunde XIII/6. München: C. H. Beck'sche Verlagsbuchandlung München.

Novotná M. 1984. Halsringe und Diademe in der Slowakei. Prähistorische Bronzefunde XI/4, München: C. H. Beck'sche Verlagsbuchandlung München.

Okulicz Ł. 1976. Osadnictwo strefy wschodniobaltyckiej w I tysiącleciu przed nasza erą. Wrocław Warszawa - Kraków - Gdańsk: Ossolineum.

Poklewski T. 1954. Halsztacki zespół ozdób brązowych z Wakijowa, pow. Tomaszów Lubelski. Wiadomości Archeologiczne 20, 267-275.

Ralska-Jasiewiczowa M. 1999. Zmiany roślinności w późnym holocenie i ich związek z rozwojem osadnictwa. In L. Starkel (ed.), Geografia Polski. Środowisko przyrodnicze. Warszawa: Wydawnictwo Naukowe PWN w Warszawie, 119-127.

Rogatko J. 1990. Zabytki z kolekcji Piotra Kani z Gródka nad Bugiem, woj. zamojskie. Lubelskie Materiaty Archeologiczne 3, 183-200. 
Sadowski S. 2012. Nowe znalezisko czekana typu scytyjskiego z południowo-wschodniej Polski. In W. Blajer (ed.), Peregrinationes archaeologicae in Asia et Europa Joanni Chochorowski dedicatae, Kraków: Wydawnictwo Profil-Archeo w Pękowicach k/Krakowa, 385-390.

Salaš M. 2005. Bronzové depoty střední až pozdní doby bronzové na Moravě a ve Slezsku (I i II), Brno: Moravské zemské muzeum.

Schmid-Sikimić B. 1996. Der Arm- und Beinschmuck der Hallstattzeit in der Schweiz: mit einem Anhang der Gürtelhaken und Gürtelhänge der Hallstattzeit im schweizerischen Mittelland, Jura und Wallis. Prähistorische Bronzefunde X/5. Stuttgart: Franz Steiner Verlag Stuttgart.

Sommerfeld Ch. 1994. Gerätegeld Sichel. Studien zur monetären Struktur bronzezeitlicher Horte im nördlichen Mitteleuropa (= Vorgeschichtliche Forschungen 19). Berlin-New York: Walter de Gruyter \& Co.

Stańczyk D. 1996. Pogranicze polsko-ruskie odcinka nadbużańskiego w świetle źródeł ruskich XII XIV wieku i w historiografii. In. M. Parczewski and S. Czopek (eds.), Poczq̨tki sqsiedztwa. Pogranicze etniczne polsko-rusko-stowackie $w$ średniowieczu. Rzeszów: Wydawnictwo Poligrafia Mitel w Rzeszowie, 205-213.

Sulimirski T. 1931. Kultura wysocka. Kraków: Wydawnictwo PAU w Krakowie.

Sulimirski T. 1936. Scytowie na Zachodniem Podolu. Lwów: Lwowskie Towarzystwo Prehistoryczne we Lwowie.

Terenozhkin A. I. 1976. Kimmerijcy. Kiev: Izdatelstvo „Naukova Dumka”.

Sprockhoff E. 1956. Jungbronzezeitliche Hortfunde der Südzone des Nordischen Kreises (Periode V). Mainz: Römisch-Germanisches Zentralnuseum.

Urban D. 2004. Siedliska hydrogeniczne oraz geneza i ewolucja wybranych torfowisk dolinowych Wyżyny Lubelskiej i Wołyńskiej. Lublin: Wydawnictwo Akademii Rolniczej w Rzeszowie.

Waluś A. 1982. Dwa warsztaty odlewnictwa brązu z osiedla obronnego kultury kurhanów zachodniobałtyjskich w Tarławkach, woj. suwalskie. Pamiętnik Muzeum Miedzi 1, 243-248.

Wichrowski Z. 1989. Osadnictwo kultury łużyckiej we Wronowicach-Paprzycy, woj. zamojskie, stan. 5a i 5b. Prace i Materiaty Zamojskie 2, 98-138.

Woźniak M. 2009. Komarów stan. 9. Cmentarzysko kultury hużyckiej w południowo-wschodniej Lubelszczyźnie. Warszawa (typescript of MA thesis in the Archive of Institute of Archaeology, Warsaw University).

Żurowski J. 1927. Skarby halsztackiego okresu z doliny Dunajca. Prace i Materjały Antropologiczno-Archeologiczne i Etnograficzne 4, 3-112+ tabl.

Żurowski K. 1948-1949. Zabytki brązowe z młodszej epoki brązu i wczesnego okresu żelaza z dorzecza górnego Dniestru. Przegląd Archeologiczny 8, 155-247. 